\title{
Modernization and Reuse of Cultural Heritage Building: A Turkish Case Study from the Izmir City
}

\author{
Mine Tanaç Zeren \\ Faculty of Architecture, Department of Restoration, Dokuz Eylul University, Izmir 35160, Turkey
}

\begin{abstract}
Protecting the historical heritage is a very important task because it makes up the identity of the society and the cities. Considering the future, the most important problem recently is how to protect the historical heritage, and how to benefit from it. And as an answer to this question, by benefiting from our cultural background, it is necessary to provide the contemporary requirements and to transfer this attitude to the future generations. Throughout the time, functions may change but old buildings may stay. This situation requires that the old buildings are open to a new contemporary uses. Nowadays, the variations in the functions loaded onto the places we live in are frequently put on the agenda due to the requirements which are continuously changed and developed by social and cultural effects. While faced with this kind of functional variations in order to protect the mean values, the scope of this study is described in a systematically manner as: (1) re-functioning process; (2) adaptation of the new function to the old building; and (3) design concept in the revalorization. The scope will be discussed with many implementations from Turkey and the cases are chosen from the Izmir city.
\end{abstract}

Key words: Modernization, reuse, cultural heritage.

\section{Introduction}

\subsection{Definition of Adaptive Reuse}

Historic buildings help define the character of our communities by providing a tangible link with the past. Historical buildings which reflect the cultural values, lifestyles and economic ranks of the societies in the past, are our historical inheritance, and are affected by the circumstances in time, and can even become obsolete. Obsolescence varies and may have different reasons [1]:

- The original occupants may move to more modern facilities;

- Owners cannot allocate funds necessary for maintenance;

- The original building may be too expensive to operate.

When the historical buildings are obsolete, they can be demolished very easily now that no maintenance

Corresponding author: Mine Tanaç Zeren, Dr., associate professor, research fields: architectural conservation and preservation. E-mail: mtanaczeren@gmail.com. will be applied. The historical continuity of the city and other related items would be destroyed in the event of the loss of the historical structures. On the other hand, many historical buildings possess qualities which are difficult or impossible to replicate such as the uniqueness of the architectural space organization, facade organization, structural system details, and architectural elements and details. These buildings are very important building stocks in the city centers when considered in the point of sustainability. Therefore, these cultural heritage buildings are ideal candidates for reuse. If a particular function is no longer relevant or desired, buildings may be converted to a new purpose altogether. To do this, we utilize an adaptive reuse, which is a method used to carry architectural heritage buildings first to nowadays use and then to future uses. Adaptive reuse is a process that adapts historical buildings to new uses while retaining their historical features and is an act of finding a new use for a building. 


\subsection{Urge to Preserve}

By definition, most old buildings are irreplaceable, and this gives them a special and endangered status in the eyes of many individuals. The desire to save old buildings can be based on:

- rational thinking;

- the sense of emotional dogma;

- the sense of belongings and identity;

- the sense of irreplaceable old buildings;

- interest of preserving meaningful architectural qualities.

Since the preservation movement began in the 1930s (Venice Charter), architects have advocated the retention of buildings through rehabilitation, renovation and, at the last attempt, restoration. When sometimes the buildings are in good condition but the services and technology within them are outdated, and if a particular function is no longer relevant or desired, adaptive reuse can be utilized as a method. More recently, however, recycling of entire buildings has become recognized as an important cornerstone of a sustainable approach to urban development [2].

\subsection{Purpose of Adaptive Reuses}

Adaptive reuse is a special form of refurbishment and has been successfully applied in many types of facilities including residential buildings, government buildings, industrial heritage and religious buildings.

Preservation of these buildings is important and maintains their intrinsic heritage and cultural values. The useful (effective) life of a building or other asset in the past has been particularly difficult to forecast because of premature obsolescence such as:

- physics;

- economy;

- functional technology;

- social obsolescence [3].

For these reasons, buildings can become obsolete long before their physical life comes to an end. Rehabilitation of historical buildings and suggesting them with new usages have some benefits which are:
- economic benefits;

- environmental benefits;

- social benefits.

Johnson [4] suggests that rehabilitation typically takes half to three-quarters of the time necessary to demolish and reconstruct the same floor area. The shorter development period reduces the cost of financing. This means that rehabilitated space can be created more quickly than new space, unless extensive structural reconstruction is required. Environmental benefits from rehabilitation arise through the recycling of materials, reuse of structural elements and the reduction in generated landfill waste and historical buildings are constructed using a range of quality materials (e.g., use of solid stone walls, marble floor coverings).

Historical buildings have significance and they are the memories of the society and are often in advantageous locations in the city centers which provide social benefits such as intrinsic heritage values that they have.

Adaptive reuse deals with the issues of conservation and heritage policies. When old buildings become unsuitable for their programmatic requirements, as progress in technology, politics and economics move faster than the built environment, adaptive reuse comes in as a sustainable option for the reclamation of sites [5].

Adaptive reuse is seen as an effective way of reducing urban sprawl and environmental impact [6]. By reusing an existing structure within a site, the energy required to create these spaces is lessened, as is the material waste that comes from destroying old sites and rebuilding using new materials. Through adaptive reuse, old unoccupied buildings can become suitable sites for many different types of use.

Historical buildings may have a character that can significantly contribute to the culture of a society and converse aspects of its history.

The old and unused parts of the cities become a new attractive area when the buildings can be transformed 
with suitable new uses. When adapting old buildings to new uses comes to practice, some interventions should be applied to the buildings for the needs of the new architectural programs.

In some cases, the old buildings can be preserved with all their unique architectural requirements such as facade and space organization, structural system features, architectural details, etc.. A well obtained new use may carry the old structure to nowadays use.

On the other hand, the needs of the new use may chance the originality of the old structure, and the adapted new uses may require chances in the original space organization and facade organization of the buildings. In some cases, the new adapted use may not fit the envelope of the building, and as a solution, the adapted use may alternate interventions both in interior and exterior of the building, as well as may modify the envelop and may get additions fused to the original buildings. So the selection of the new use of the historical building is a very important item to be carefully studied.

Now that it cannot be obtained practically, when preserving historical buildings comes into practice, the best way to preserve their originality with all their features is to preserve them with their original uses. The conversion of old buildings to museums is another method if the purpose is to preserve all the originality of the old buildings.

When the degree of interventions comes into question, the degree of the interventions depends on the originality and importance of the architectural fabric. It should be agreed that certain highly distinctive landmark buildings with genuine historic credentials should be preserved without any interventions, and the method of preservation of these kind of buildings leads to freezing the building in time under two possible scenarios: restoring it to its original condition and making no intervention at all. Less significant historic structures are often rehabilitated rather than faithfully restored. Rehabilitation may include a minor change from the original uses as well as the introduction of old elements. So, the adaptive reuse attempt should:

- transform the environment of the building, and turn the building and its environment a living nowadays space;

- respect and retain the spatial organization and the envelope of the existing structures;

- be eligible of preserving both the tangible and intangible value of the existing building;

- make the structure livable in the meaning of sustainability;

- not ruin the originality of the structure.

The interventions and/or additions should be recognizable and should differ from the old structure as stated in Venice Charter.

The most successful built heritage adaptive reuse projects are those that best respect and retain the building's heritage significance and add a contemporary layer that provides value for the future. Sometimes, adaptive reuse is the only way that the building's fabric will be properly cared for, revealed or interpreted, while making better use of the building itself. When a building can no longer function with its original use, a new use through adaptation may be the only way to preserve its heritage significance.

\section{Methodology}

There are often criteria for deciding whether a building should be conserved and reused or just demolished for the area of land it occupies. Some of these determining criteria include:

- the societal value of a given site, which is the importance of the use of a site to the community or visitors' use;

- the potential for the reuse of a particular site, the physical damage sustained to the site and its support of future use, the character of the existing site in terms of the proposed reuse;

- the historical importance of the site, in terms of both physicality of the street-scrape and the area, as well as the site in the community's understanding of the past; 
- the natural ecological conditions of the site, whether the site is suitable climatically or can support the proposed environmental work needed in the site.

According to preservation rules, there are methods of restoration attempts such as rehabilitation, renovation restoration and adaptive reuse.

Adaptation describes rehabilitation, renovation or restoration works that do not necessarily involve changes of use. Rehabilitation is the recycling of buildings involving restoration and new construction $[3,7,8]$. The difference is that restoration returns a building to the condition when it was originally constructed, whereas renovation modifies a building so that it meets current standards and codes. Although it extends the useful life of a building, renovation does not involve a change in use [7]. It can therefore be reasonably argued that adaptation is a method of extending the useful life of buildings and hence their sustainability by a combination of improvement and conversion [7-13]. And to decide whether the adaptive reuse attempt is successful or partly successful, or not, there are some codes to clarify it such as:

- Does the adaptive reuse attempt transform the environment of the building?

- Does the adapted function's spatial organization fit the existing structures spatial organization?

- Does the adapted function of the building eligible of preserving both the tangible and intangible value of the existing building?

- Does the adapted function make the structure livable in the meaning of sustainability?

- Do the interventions that make the structure adapt to nowadays use ruin the originality of the structure?

- Do the adapted function uses modify the envelope of the building?

- The degrees of intervention.

As the methodology of this study, the reasons of the obsolescence of the building will be clarified and cases will be analyzed in the frame of these criteria mentioned above.

\section{Definition of the Cases of the Study}

The adaptive reuse examples are selected as three categories which are:

(1) adaptive reuse attempts in residential buildings;

(2) adaptive reuse attempts in monumental buildings/religious buildings;

(3) adaptive reuse attempts in industrial buildings.

All the cases are chosen from the Izmir City, Turkey.

\subsection{Adaptive Reuse Attempts in Residential Buildings}

Residential buildings have minimal spaces in scale and less number of spaces when compared with monumental buildings. It can be said that the best way of preserving this kind of structures is restoring them by not changing the use of the building.

When the issue of selecting a new function for this kind of building type comes into practice, the new use space organization may not have the possibility of fitting the existing space organization due to the scale of the old building. As a result, the new use may transform the space organization of the old building and can even modify the envelope of the existing structure due to the new uses space needs. Hence, the structure may not transform its environment due to its dimensional state.

In this building type, two examples are studied. Both buildings are utilized with cultural purposes. Both of these two buildings are dated back to 1850 s, and are the houses of important English merchants working for railway company. Houses are facing the train station. The owners of the buildings have left the city in 1922, and, since that period of time, the buildings were used for different purposes. In 2008, the municipality owned the houses and transformed them with cultural facilities. The purpose of the adaptive reuse attempts is to converge the public with these 19th century Levantine buildings and heritage.

The buildings are located in a courtyard, and the entrances of the buildings are from the street. The ground floor of the houses has four rooms and serves as the living spaces. There is a semi-floor for services, and 
the first floor has four rooms as well for sleeping facilities.

\subsubsection{Case 1: Public Library}

The first example is an adaptive reuse attempt from a residential building to a public library. The facade end envelope of the old building has been preserved with all its uniqueness as the representative of the 19th century face of the city. When utilizing process comes into practice, now that the library use needs large spaces for exhibiting the books and reading facilities. The space organization of the interior is transformed, and the walls of the rooms are removed to form larger spaces. With this new function, the building retained all its architectural features to future. The adaptive reuse attempt of the building can be taken into consideration as a successful approach as it turned the structure into a livable place by the public in the meaning of sustainability (Figs. 1a-1c, Table 1).

\subsubsection{Case 2: Music Museum}

The second example is an adaptive reuse attempt from a residential building to a museum space. The facade end envelope of the old building has been preserved with all its uniqueness as the representative of the 19th century face of the city as in the first example. When utilizing process comes into practice, the old building is preserved with its unique space organization, and the rooms are transformed into exhibition rooms for musical instruments. The new programme gave birth to a concert hall which is for musical performances. So a new building was extended to the old structure in order to meet the needs of museums space programme.

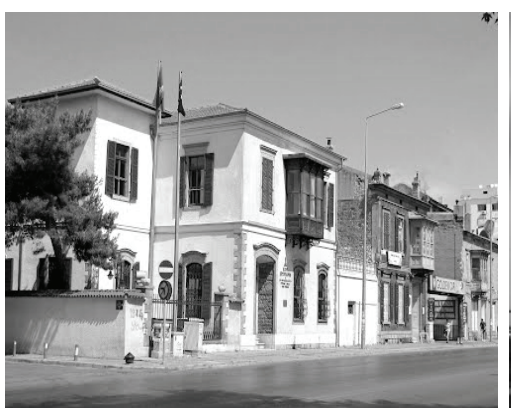

(a)

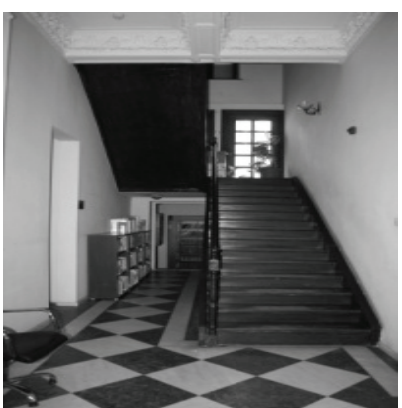

(b)

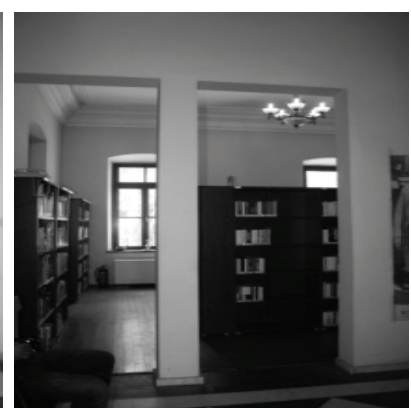

(c)

Fig. 1 Public library: (a) the street facade of the building; (b) and (c) the interior.

Table 1 Case 1: public library.

\begin{tabular}{|c|c|c|c|c|c|}
\hline $\mathrm{X}$ evaluates from $1 \sim 5$ (adequate to inadequate) & 1 & 2 & 3 & 4 & 5 \\
\hline $\begin{array}{l}\text { Does the adaptive reuse attempt transform the } \\
\text { environment of the building? }\end{array}$ & & & & $\mathrm{X}$ & \\
\hline $\begin{array}{l}\text { Does the adapted function's spatial organization fit } \\
\text { to the existing structures spatial organization? }\end{array}$ & $\mathrm{X}$ & & & & \\
\hline $\begin{array}{l}\text { Does the adapted function of the building eligible } \\
\text { of preserving both the tangible and intangible value } \\
\text { of the existing building? }\end{array}$ & & & $\mathrm{X}$ & & \\
\hline $\begin{array}{l}\text { Does the adapted function make the structure } \\
\text { livable in the meaning of sustainability? }\end{array}$ & & & & $\mathrm{X}$ & \\
\hline $\begin{array}{l}\text { Do the interventions that make the structure adapt } \\
\text { to nowadays use ruin the originality of the } \\
\text { structure? }\end{array}$ & $\mathrm{X}$ & & & & \\
\hline $\begin{array}{l}\text { Does the adapted function uses modify the } \\
\text { envelope of the building? }\end{array}$ & $\mathrm{X}$ & & & & \\
\hline \multirow[t]{2}{*}{ The degrees of the interventions } & $\begin{array}{l}\text { Space } \\
\text { organization }\end{array}$ & $\begin{array}{l}\text { Envelope of } \\
\text { the building }\end{array}$ & $\begin{array}{l}\text { Additions to } \\
\text { interior }\end{array}$ & $\begin{array}{l}\text { Additions to } \\
\text { exterior }\end{array}$ & $\begin{array}{l}\text { Intangible } \\
\text { values }\end{array}$ \\
\hline & Not preserved & Preserved & No additions & No additions & Not preserved \\
\hline \multirow{2}{*}{ The reasons of the obsolescence of the building } & Physical & Economic & Functional & Technological & Social \\
\hline & & & $\mathrm{X}$ & & $\mathrm{X}$ \\
\hline
\end{tabular}




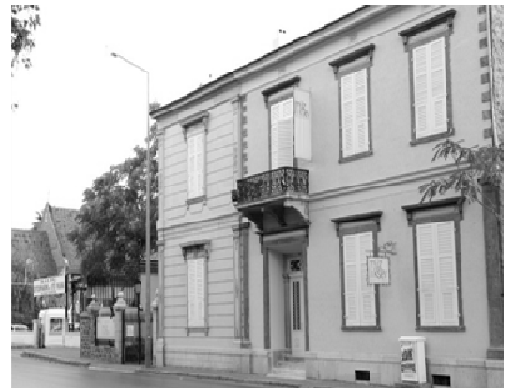

(a)

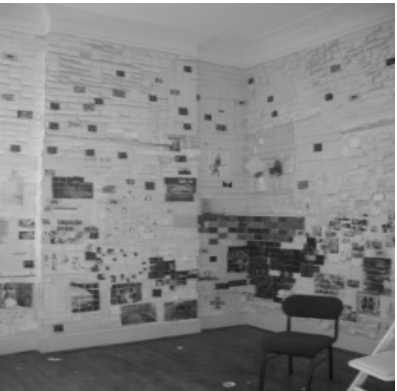

(b)

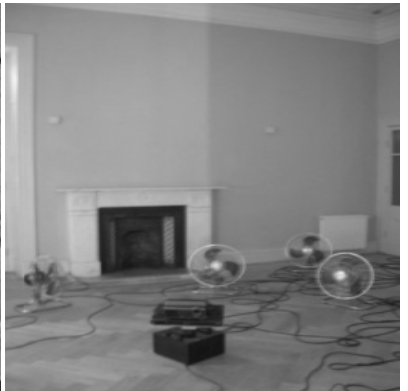

(c)

Fig. 2 Music museum: (a) the street view of the building; (b) and (c) an interior view from an exhibition.

Table 2 Case 2: music museum.

\begin{tabular}{|c|c|c|c|c|c|}
\hline $\mathrm{X}$ evaluates from $1 \sim 5$ (adequate to inadequate) & 1 & 2 & 3 & 4 & 5 \\
\hline $\begin{array}{l}\text { Does the adaptive reuse attempt transform the } \\
\text { environment of the building? }\end{array}$ & & & & $\mathrm{X}$ & \\
\hline $\begin{array}{l}\text { Does the adapted function's spatial organization fit } \\
\text { to the existing structures spatial organization? }\end{array}$ & & & $\mathrm{X}$ & & \\
\hline $\begin{array}{l}\text { Does the adapted function of the building eligible } \\
\text { of preserving both the tangible and intangible value } \\
\text { of the existing building? }\end{array}$ & & & $\mathrm{X}$ & & \\
\hline $\begin{array}{l}\text { Does the adapted function make the structure } \\
\text { livable in the meaning of sustainability? }\end{array}$ & & & & $\mathrm{X}$ & \\
\hline $\begin{array}{l}\text { Do the interventions that make the structure adapt } \\
\text { to nowadays use ruin the originality of the structure }\end{array}$ & $\mathrm{X}$ & & & & \\
\hline $\begin{array}{l}\text { Does the adapted function uses modify the } \\
\text { envelope of the building? }\end{array}$ & & & & $\mathrm{X}$ & \\
\hline \multirow{2}{*}{ The degrees of the interventions } & $\begin{array}{l}\text { Space } \\
\text { organization }\end{array}$ & $\begin{array}{l}\text { Envelope of } \\
\text { the building }\end{array}$ & $\begin{array}{l}\text { Additions to } \\
\text { interior }\end{array}$ & $\begin{array}{l}\text { Additions to } \\
\text { exterior }\end{array}$ & $\begin{array}{l}\text { Intangible } \\
\text { values }\end{array}$ \\
\hline & Preserved & Not preserved & No additions & A concert hall & Not preserved \\
\hline \multirow{2}{*}{ The reasons of the obsolescence of the building } & Physical & Economic & Functional & Technological & Social \\
\hline & & & $\mathrm{X}$ & & $\mathrm{X}$ \\
\hline
\end{tabular}

With this new function, the building retained all its architectural features to future. The adaptive reuse attempt of the building can be taken into consideration as a successful approach as it turned the structure into a livable place by the public in the meaning of sustainability (Figs. 2a-2c, Table 2).

\subsection{Adaptive Reuse Attempts in Monumental Buildings/Religious Buildings}

The issue of vacant and disused religious buildings is a significant concern to our built environment. There are a variety of factors which may bring about the redundancy of a religious building. Each building will have its own particular set of causes. The value of a religious building can be described through several factors which together contribute to cultural sustainability such as historic importance and continuity, aesthetic and architectural merit, community value, townscape value and social landscape.

Adaptation should always require careful consideration to achieve a balance between the requirements of a new function whilst retaining the historical continuity. Religious buildings differ from the monumental buildings with their unsocial space behavior [5] when restoring religious buildings comes into practice. This case is even harder than restoring any kind of monumental buildings, now that they have a slightly more special significance than all other monumental buildings. But despite all of these, there are countless reuse examples obtained to religious buildings starting from museums including the residential conversions. Sephardic synagogue in Amsterdam can be an example for the conversions to museum. Lancester Gate Church in London can be 
given as an example of the conversion to a residential space [5].

Two religious buildings will be given as an example: an orthodox church and a Sephardic synagogue that are utilized by a reuse.

\subsubsection{Case 3: Ayavukla Church}

The church is Agios Voukolos (AyaVukla in Turkish), which is located in Izmir's former Armenian Basmane district. Aya Vukla Church has a symbolic and historical value since it reflects the cultural variety of Izmir. It is a 19th century orthodox church that exhibits the features of neoclassical architecture with its decorations inside. Upon the request of the Izmir Metropolitan Municipality, a restoration project was carried out. Now newly restored, it will be used as a cultural center.

The name of the church holds strong historical ties to the city. Named after the orthodox Christian Saint Voukolos, who was a student of Saint John, the evangelist, he became the first bishop of Smyrna. The church was constructed in 1860 during a time when Greeks and Armenians were incredibly prosperous within the Ottoman Empire, thus, the church served the Greeks and Armenian Christians, as it was referred to as "Hayhurum", meaning Armenian-Greeks. During this time, there were several large churches including Aghia Fotini and Aghios Giorgos, located in Alsancak and Konak, however after the Great Fire of Smyrna in 1922, all were burned down, leaving Aya Vukla the lone surviving Greek orthodox church in downtown Izmir. Aya Vukla Church contains lots of important events in its history. It was used as a depot of the State Opera and Ballet Institution between 1985 and 1999 [14] (Figs. 3a-3c, Table 3).

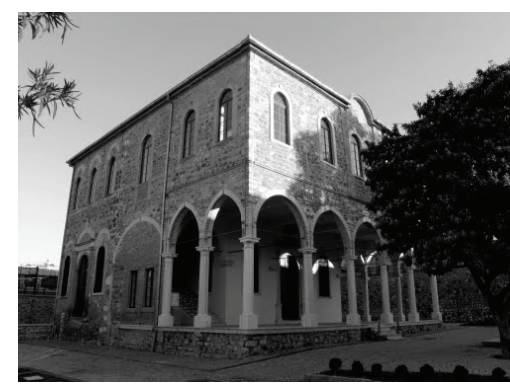

(a)

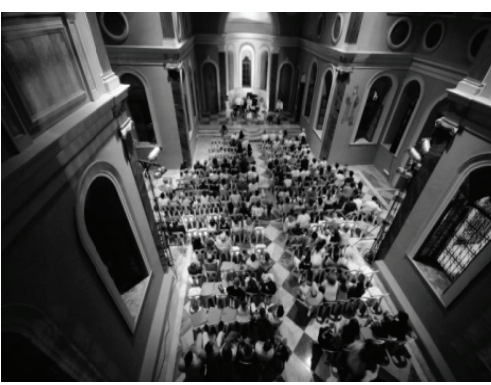

(b)

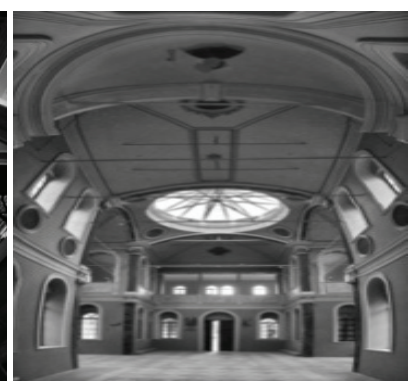

(c)

Fig. 3 (a) Ayavukla Church; (b) interior view from a concert event after the restoration process; (c) interior of the church building.

Table 3 Case 3: Ayavukla Church.

\begin{tabular}{|c|c|c|c|c|c|}
\hline $\mathrm{X}$ evaluates from $1 \sim 5$ (adequate to inadequate) & 1 & 2 & 3 & 4 & 5 \\
\hline $\begin{array}{l}\text { Does the adaptive reuse attempt transform the } \\
\text { environment of the building? }\end{array}$ & & & & $\mathrm{X}$ & \\
\hline $\begin{array}{l}\text { Does the adapted function's spatial organization fit } \\
\text { to the existing structures spatial organization? }\end{array}$ & & & & & $\mathrm{X}$ \\
\hline $\begin{array}{l}\text { Does the adapted function of the building eligible } \\
\text { of preserving both the tangible and intangible value } \\
\text { of the existing building? }\end{array}$ & & & $\mathrm{X}$ & & \\
\hline $\begin{array}{l}\text { Does the adapted function make the structure } \\
\text { livable in the meaning of sustainability? }\end{array}$ & & & & $\mathrm{X}$ & \\
\hline $\begin{array}{l}\text { Do the interventions that make the structure adapt } \\
\text { to nowadays use ruin the originality of the structure? }\end{array}$ & $\mathrm{X}$ & & & & \\
\hline $\begin{array}{l}\text { Does the adapted function uses modify the } \\
\text { envelope of the building? }\end{array}$ & $\mathrm{X}$ & & & & \\
\hline \multirow[t]{2}{*}{ The degrees of the interventions } & $\begin{array}{l}\text { Space } \\
\text { organization }\end{array}$ & $\begin{array}{l}\text { Envelope of } \\
\text { the building }\end{array}$ & $\begin{array}{l}\text { Additions to } \\
\text { interior }\end{array}$ & $\begin{array}{l}\text { Additions to } \\
\text { exterior }\end{array}$ & $\begin{array}{l}\text { Intangible } \\
\text { values }\end{array}$ \\
\hline & Preserved & Preserved & No additions & No additions & Not preserved \\
\hline \multirow{2}{*}{ The reasons of the obsolescence of the building } & Physical & Economic & Functional & Technological & Social \\
\hline & & & $\mathrm{X}$ & & $\mathrm{X}$ \\
\hline
\end{tabular}


The reason of obsolesces of this building is firstly social and secondly functional. The building lost its orthodox congregation and therefore it has not been used as a church since 1922. The municipality utilized this building with a new use as a cultural center which is planned to be served for all the public of the city. The adaptive reuse attempt of the building can be taken into consideration as a successful approach as it turned the structure into a livable place by the public in the meaning of sustainability, the spatial organization, the envelope of the original structure retained. The Ayavukla Church is opened to the citizens of Izmir, and citizens can use this building which is one of the most important remembrances of their city's history for cultural occasions. Now that this building is a large building in scale, the adaptive reuse attempt dominated the environment of the building as well. The isolated environment started to be used by the public. The building retained its continuity with all its tangible features, now that the orthodox congregation has left the town in 1922, and the intangible features were all lost since that period of time.

\subsubsection{Case 4: Kaal Kadosh Synagogue}

Kaal Kadosh Synagogue Building in Izmir is established in the very beginning of 20th century, and is one of the representatives of basilica plan typed synagogues with its neoclassical façade. Now it is used as a conservatory, and the interior and envelope of the building are preserved as its original. This building can be shown as a good example for the adaptive reuse. Even if this place is not used for the religious function, the space organization of the synagogue was not demolished, and preserved as it used to be [15] (Figs. 4a-4c, Table 4).

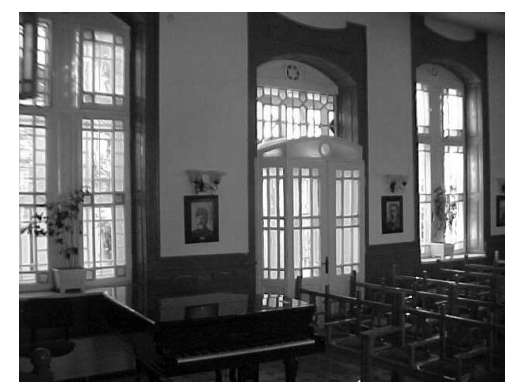

(a)

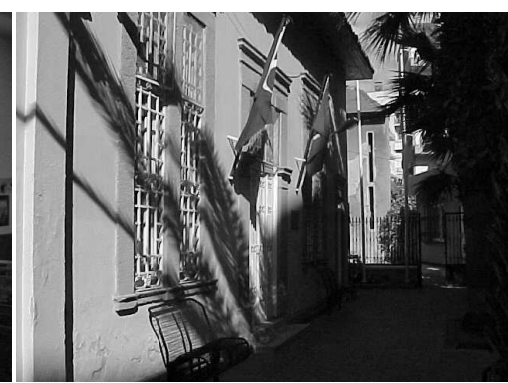

(b)

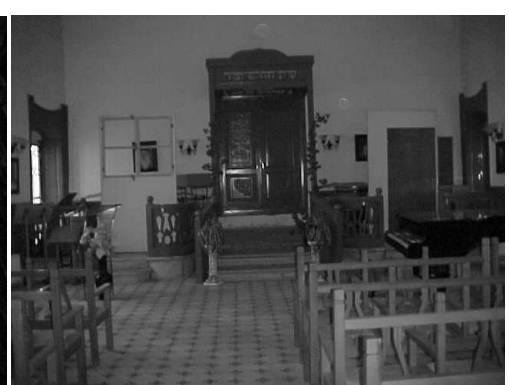

(c)

Fig. 4 Kaal Kadosh Synagogue: (a) interior of the Synagogue; (b) exterior of the Synagogue; (c) interior of the Synagogue.

Table 4 Case 4: Kaal Kadosh Synagogue.

\begin{tabular}{|c|c|c|c|c|c|}
\hline $\mathrm{X}$ evaluates from $1 \sim 5$ (adequate to inadequate) & 1 & 2 & 3 & 4 & 5 \\
\hline $\begin{array}{l}\text { Does the adaptive reuse attempt transform the } \\
\text { environment of the building? }\end{array}$ & & & & $\mathrm{X}$ & \\
\hline $\begin{array}{l}\text { Does the adapted function's spatial organization fit } \\
\text { to the existing structures spatial organization? }\end{array}$ & & & & & $\mathrm{X}$ \\
\hline $\begin{array}{l}\text { Does the adapted function of the building eligible } \\
\text { of preserving both the tangible and intangible value } \\
\text { of the existing building? }\end{array}$ & & & $\mathrm{X}$ & & \\
\hline $\begin{array}{l}\text { Does the adapted function make the structure } \\
\text { livable in the meaning of sustainability? }\end{array}$ & & & & & $\mathrm{X}$ \\
\hline $\begin{array}{l}\text { Do the interventions that make the structure adapt } \\
\text { to nowadays use ruin the originality of the } \\
\text { structure? }\end{array}$ & $\mathrm{X}$ & & & & \\
\hline $\begin{array}{l}\text { Does the adapted function uses modify the } \\
\text { envelope of the building? }\end{array}$ & $\mathrm{X}$ & & & & \\
\hline \multirow[t]{2}{*}{ The degrees of the interventions } & $\begin{array}{l}\text { Space } \\
\text { organization }\end{array}$ & $\begin{array}{l}\text { Envelope of } \\
\text { the building }\end{array}$ & $\begin{array}{l}\text { Additions to } \\
\text { interior }\end{array}$ & $\begin{array}{l}\text { Additions to } \\
\text { exterior }\end{array}$ & $\begin{array}{l}\text { Intangible } \\
\text { values }\end{array}$ \\
\hline & Preserved & Preserved & No additions & No additions & Not preserved \\
\hline \multirow{2}{*}{ The reasons of the obsolescence of the building } & Physical & Economic & Functional & Technological & Social \\
\hline & & & $\mathrm{X}$ & & $\mathrm{X}$ \\
\hline
\end{tabular}




\subsection{Adaptive Reuse Attempts in Industrial Buildings}

Industrial buildings are especially well suited to adaptive reuse due to their large open spaces. The decline of heavy industry during the early and mid-20th century has left a legacy of abandoned, idled, and underutilized dormant sites. Adaptive reuse of these types of buildings should be preferred when no other industrial option is available and should be favored over demolition and redevelopment $[3,10,16]$. There are countless reuse options available for industrial buildings such as museums, art studios, live-work units, offices, residential units, schools, etc.. Above all, the most important thing should be to preserve the historical heritage with all its tangible and intangible features. Two adaptive reuse examples will be discussed in this part of the study. Both examples are chosen from the Izmir city. One is transformed with a cultural use, and the second one is transformed with an educational use.

\subsubsection{Case 5: Gas Plant Building}

The gas plant building is one of the important industry buildings of Izmir built in the mid of 19th century by French [14]. The main factory building and its annexes located on a $24,000 \mathrm{~m}^{2}$ land. This building and its environment were re-adapted by Izmir Municipality as a cultural platform for public as the industrial archeology site. The renovated building complex played a very important role in reducing the urban sprawl of the area, transformed its environment, enhanced the aesthetic appeal of the built environment, increased the demand for retained existing buildings, and retained streetscapes that maintain the sense of place, visual amenity and cultural heritage. The adaptive reuse attempt of the building can be taken into consideration as successful because mainly it turned the structure into a livable place by the public in the meaning of sustainability, the spatial organization, the envelope of the original structure has been carried out to future use, the tangible and intangible values have been preserved as well (Figs. 5a-5c, Table 5).

\subsubsection{Case 6: Flour Mill Building}

The first owner of the flour mill was a Greek merchant and the building was built in 1895 . Between 1913-1915, the building was one of the 6th flour mills in Izmir [14]. The mill was bought by Rahmi Filibeli in 1920, Filibeli renovated the factory building in 1941 by an English firm Robinson. A second factory building was added to the complex in 1954 [14]. The building was used for example for depots during 1960s to 1996 and was later on sold to Yasar University. Since 2002, the building has been used for educational purposes and converted to a university building. The adaptive reuse attempt of the building can be taken into consideration as a unsuccessful approach even though it turned the structure into a livable place by the public in the meaning of sustainability, but the spatial organization, the envelope of the original structure cannot be retained, the intangible values have been all removed, and there are no features of the flour mill building left except a standing two storied outside wall. The university use needed such small spaces to be able to be used as classrooms or other facilities. So the large spaced space organization did not fit the new uses needs. What has been preserved is only the facade of the building (Fig. 6, Table 6).

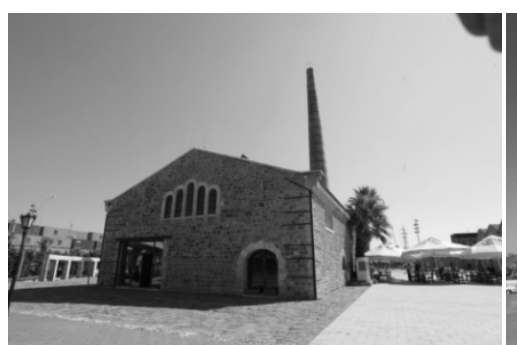

(a)

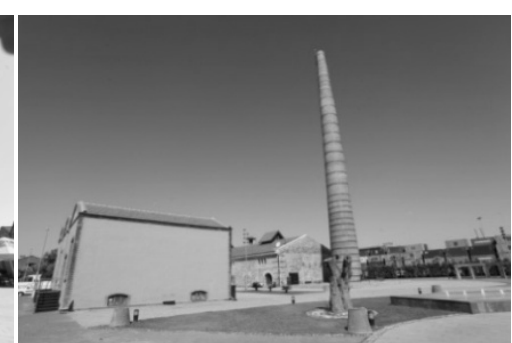

(b)

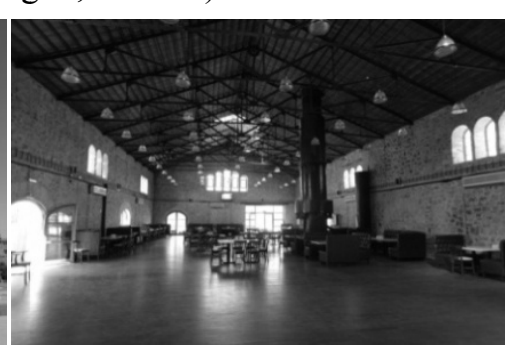

(c)

Fig. 5 Gas plant building: (a) the main factory building; (b) the main factory building and the houses of the workman; (c) interior of the main factory building. 
Table 5 Case 5: gas plant building.

\begin{tabular}{|c|c|c|c|c|c|}
\hline $\mathrm{X}$ evaluates from $1 \sim 5$ (adequate to inadequate) & 1 & 2 & 3 & 4 & 5 \\
\hline $\begin{array}{l}\text { Does the adaptive reuse attempt transform the } \\
\text { environment of the building? }\end{array}$ & & & & $\mathrm{X}$ & \\
\hline $\begin{array}{l}\text { Does the adapted function's spatial organization fit } \\
\text { to the existing structures spatial organization? }\end{array}$ & & & $X$ & & \\
\hline $\begin{array}{l}\text { Does the adapted function of the building eligible } \\
\text { of preserving both the tangible and intangible value } \\
\text { of the existing building? }\end{array}$ & & & $\mathrm{X}$ & & \\
\hline $\begin{array}{l}\text { Does the adapted function make the structure } \\
\text { livable in the meaning of sustainability? }\end{array}$ & & & & & $\mathrm{X}$ \\
\hline $\begin{array}{l}\text { Do the interventions that make the structure adapt } \\
\text { to nowadays use ruin the originality of the structure? }\end{array}$ & $\mathrm{X}$ & & & & \\
\hline $\begin{array}{l}\text { Does the adapted function uses modify the } \\
\text { envelope of the building? }\end{array}$ & $\mathrm{X}$ & & & & \\
\hline \multirow{2}{*}{ The degrees of the interventions } & $\begin{array}{l}\text { Space } \\
\text { organization }\end{array}$ & $\begin{array}{l}\text { Envelope of } \\
\text { the building }\end{array}$ & $\begin{array}{l}\text { Additions to } \\
\text { interior }\end{array}$ & $\begin{array}{l}\text { Additions to } \\
\text { exterior }\end{array}$ & $\begin{array}{l}\text { Intangible } \\
\text { values }\end{array}$ \\
\hline & Preserved & Preserved & $\begin{array}{l}\text { A mezzanine } \\
\text { floor was added }\end{array}$ & No addition & Preserved \\
\hline \multirow{2}{*}{ The reasons of the obsolescence of the building } & Physical & Economic & Functional & Technological & Social \\
\hline & & $\mathrm{X}$ & $\mathrm{X}$ & $\mathrm{X}$ & \\
\hline
\end{tabular}

(1)

Fig. 6 Flour mill building.

Table 6 Case 6: flour mill building.

\begin{tabular}{|c|c|c|c|c|c|}
\hline $\mathrm{X}$ evaluates from $1 \sim 5$ (adequate to inadequate) & 1 & 2 & 3 & 4 & 5 \\
\hline $\begin{array}{l}\text { Does the adaptive reuse attempt transform the } \\
\text { environment of the building? }\end{array}$ & & $\mathrm{X}$ & & & \\
\hline $\begin{array}{l}\text { Does the adapted function's spatial organization fit } \\
\text { to the existing structures spatial organization? }\end{array}$ & $\mathrm{X}$ & & & & \\
\hline $\begin{array}{l}\text { Does the adapted function of the building eligible } \\
\text { of preserving both the tangible and intangible value } \\
\text { of the existing building? }\end{array}$ & $\mathrm{X}$ & & & & \\
\hline $\begin{array}{l}\text { Does the adapted function make the structure } \\
\text { livable in the meaning of sustainability? }\end{array}$ & & & & $\mathrm{X}$ & \\
\hline $\begin{array}{l}\text { Do the interventions that make the structure adapt } \\
\text { to nowadays use ruin the originality of the structure? }\end{array}$ & $\mathrm{X}$ & & & & \\
\hline $\begin{array}{l}\text { Does the adapted function uses modify the } \\
\text { envelope of the building? }\end{array}$ & $\mathrm{X}$ & & & & \\
\hline \multirow[b]{2}{*}{ The degrees of the interventions } & $\begin{array}{l}\text { Space } \\
\text { organization }\end{array}$ & $\begin{array}{l}\text { Envelope of } \\
\text { the building }\end{array}$ & $\begin{array}{l}\text { Additions to } \\
\text { interior }\end{array}$ & $\begin{array}{l}\text { Additions to } \\
\text { exterior }\end{array}$ & $\begin{array}{l}\text { Intangible } \\
\text { values }\end{array}$ \\
\hline & Not preserved & $\begin{array}{l}\text { Partly } \\
\text { preserved }\end{array}$ & $\begin{array}{l}\text { Floor plans } \\
\text { changed, divided } \\
\text { partly to form } \\
\text { classrooms }\end{array}$ & $\begin{array}{l}\text { A third floor was } \\
\text { added }\end{array}$ & Not preserved \\
\hline \multirow{2}{*}{ The reasons of the obsolescence of the building } & Physical & Economic & Functional & Technological & Social \\
\hline & & $\mathrm{X}$ & $\mathrm{X}$ & $\mathrm{X}$ & \\
\hline
\end{tabular}




\section{Discussion and Conclusions}

Old buildings often outlive their original purposes. Adaptive reuse, or reuse, is a process that adapts buildings for new uses while retaining their historic features. Although there are many qualifying factors, the concept of adaptive reuse has significant support as a positive strategy to make the built environment more sustainable. Adaptive reuse enhances the longer-term usefulness of a building and is therefore a more sustainable option than demolition and rebuilding. On the other hand, it is a very important tool in preserving the architectural heritage buildings. The buildings that lose their functions and which are outdated would be the part of the nowadays use with their new uses. This item retains the continuity of historical environment, identity of the city, revitalizes existing neighborhoods, reduces land consumption and urban sprawl, and retains visual amenity and cultural heritage, streetscapes that maintain sense of place.

One should take the preservation and utilization equilibrium into account. The suggested new use should not be in advance on the historical building, or on the contrary. In order to preserve the cultural heritage:

- the adapted function's spatial organization should be in balance with the existing structures spatial organization;

- the adapted function of the building should be eligible of preserving both the tangible and intangible values of the existing building;

- the adapted function should make the structure livable in the meaning of sustainability;

- the interventions that make the structure adapt to nowadays use should not ruin the originality of the structure;

- the adapted function uses should not modify the envelope of the building or if an extension will be needed due to new use, the extension-addition should be in balance with the existing structure;

- the adaptive reuse attempt should transform the environment of the building.

So when the preservation and utilization processes would be in balance with each other, the new use could make the structure livable in the meaning of sustainability, and make the existing structure dominate its environment, then it may be said that the adaptive reuse attempt has reached its goal in both preserving the historical features of the building and the continuity of the structure.

At the broadest level, the historical and cultural heritage belongs to all people. We each have a right and responsibility to understand, appreciate and conserve its universal values. Our past is the most important resource in creating our future, and leads us to integrate our cultural identities with our new living environments. Obviously, the cultural and historical values that one cultural landscape or city owns form the local identity of that settlement.

Keeping and reusing historic buildings have long-term benefits for the communities that value them. When done well, adaptive reuse can restore and maintain the heritage significance of a building and help to ensure its survival. Rather than falling into disrepair through neglect or being rendered unrecognizable, heritage buildings that are sympathetically recycled can continue to be used and appreciated.

\section{References}

[1] Kuban, D. 2000. Tarihi Çevre Korumanin Mimarlk Boyutu (Preservation of Historical Environment in the Point of View of Architecture). İstanbul: YEM Yayınları. (in Turkish)

[2] Bloszies, C. 2012. Old Buildings, New Designs Architectural Transformations. New York: Princton Architectural Press.

[3] Gregory, J. 2004. "Rehabilitation-New Ways for Older Housing." New South Wales Department of Housing. Accessed January 2012. http://www.housing.nsw.gov.au/rehab.htm.

[4] Johnson, A. 1996. "Rehabilitation and Reuse of Existing Buildings." In Building Maintenance and Preservation: A Guide to Design and Management, edited by Mills, E. D. 2nd ed.. Oxford: Architectural Press. 
[5] Zeren, M. T. 2011. "Adaptive Reuse of Monuments: Restoring Religious Buildings with Different Uses." In Proceedings of 5th International Congress on Science and Technology for the safeguard of Cultural Heritage in the Mediterranean Basin, 22-5.

[6] Altinoluk, Ü. 1998. Binaların Yeniden Kullanımı (Re-functioning of the Buildings). İstanbul: YEM Yayınlar1. (in Turkish)

[7] Douglas, J. 2002. Building Adaptation. Woburn: Butterworth-Heinemann.

[8] English Heritage. 2000. Power of Place: The Future of the Historic Environment. London: English Heritage.

[9] Cooper, I. 2001. "Post-occupancy Evaluation-Where Are You?.” Building Research \& Information 29 (2): 158-63.

[10] Holyoake, K., and Watt, D. 2002. "The Sustainable Reuse of Historic Urban Industrial Buildings: Interim Results and Discussion." In Proceedings of the RICS Foundation Construction and Building Research Conference. Accessed August http://www.rics-foundation.org/ index.html.

[11] Kohler, N., and Hassler, U. 2002. "The Building Stock as a Research Object.” Building Research \& Information 30 (4): 226-36.

[12] Lowe, R. J. 2004. "Lessons from Climate Change: A Response to the Commentaries." Building Research \& Information 32 (1): 75-8.

[13] Seeley, I. H. 1983. Building Economics: Appraisal and Control of Building Design Cost and Efficiency. 3rd ed. USA: Macmillan Press.

[14] Güner, D. 2005. Architectural Guide Book of Izmir. İzmir: Mimarlar Odası Yayınevi.

[15] Tanac, M. 2003. "Osmanlı Kentlerinde Sefarad Kültürünün Dönüşümünün Mimariye Yansıması İzmir Örneği (Reflections of Sefardim Culture in Ottoman Cities Case Izmir).” Ph.D. thesis, Dokuz Eylul University. (in Turkish)

[16] Thiel-Siling, S. 1998. Icons of Architecture. New York: Pretzel Press. 